\title{
E-COMMERCE KEPADA PEDAGANG KAKI LIMA DAN UMKM KOTA PAYAKUMBUH UNTUK MENINGKATKAN DAYA SAING DI ERA GLOBAL
}

\author{
Winny Alna Marlina*), Bintang Rizky Abdullah Majo Saibah, Ranny Fitriana Faisal, \\ Agestayani, Erizal, Susiana' Musbatiq Srivani, Faisal Ali Ahmad
}

\author{
Fakultas Ekonomi Universitas Andalas \\ ${ }^{*}$ Email: winnyalnamarlina@eb.unand.ac.id
}

\begin{abstract}
ABSTRAK
Payakumbuh merupakan salah satu kota di Sumatera Barat yang memiliki kuliner malam sehingga pedagang kaki lima paling sejumlah 254 pedagang. Pedagang ini tidak memiliki tempat jualan dan kurang promosi. sehingga dibuatkan website untuk mempromosikan bisnisnya. Tujuan diadakan kegiatan pengabdian kepada masyarakat agar menambah wawasan dan pengetahuan kepada pedagang kaki Lima di Payakumbuh tentang teknologi khususnya dalam e-commerce. Kegiatan pengabdian dilakukan pada tanggal 19 November 2018 di Universitas Andalas Campus 2 Payakumbuh. Metode yang dilakukan dengan metode ceramah dan praktik langsung. Dalam hal ini membagi ilmu pengetahuan tentang ecommerce serta cara pormosi dalam penjualan. Peserta setelah mengetahui cara membuat social media lalu langsung mempraktekannya. Hasil dari kegiatan berupa website kulinerpayakumbuh.com sebagai sarana untuk membantu mempromosikan usaha pedagang kaki lima dan UMKM di Payakumbuh. Peserta memahami perlunya e-commerce untuk memasarkan dagangannya, $46 \%$ peserta mendapatkan manfaat kegiatan menjadi mengetahui cara promosi dari website, kemudian $41 \%$ menambah wawasan dan $13 \%$ membantu perkembangan usahanya kedepan. Peserta berharap kegiatan pengabdian ini terus dilaksanakan.
\end{abstract}

Kata Kunci: Ecommerce, pengabdian masyarakat, pedagang kaki lima, UMKM

\section{Socialization and Training: Implementing Ecommerce to Street Vendors and Payakumbuh City UMKM to enhance SME Competitiveness}

\begin{abstract}
Payakumbuh is one of City on Sumatera Barat where having many street foods at night around 254 retailers. These food night retailers always move from another place to another place and lack of promotion. The purpose of our community service program is to enhance knowledge of street vendorts/retailers in Payakumbuh regarding technology especially e-commerce. The method of this is sharing and transferring knowledge and exercise. It was expected that participants will have a greater understanding in how to make the most of social media for business. The result of this public free service activity is kulinerpayakumbuh.com for helping promotion of the street food retailers in Payakumbuh. Based on our survey after this activity, the merchants were able to promote their products through the website, thus $41 \%$ participant could elevate their knowledge, and 13\% participant could implement ecommerce to their business.
\end{abstract}

Keywords: Ecommerce, community service, street vendor, UMKM 


\section{PENDAHULUAN}

Pada Pasal 20 Undang-undang Nomor 20 Tahun 2003 tentang Sistem Pendidikan Nasional mengemukanan bahwa kewajibandari Perguruan Tinggi selain melaksanakan pendidikan ialah untuk menyelenggarakan penelitian dan pengabdian masyarakat. Undang-undang Nomor 12 Tahun 2012 Pasal 45 tentang Pendidikan Tinggi juga menegasakan bahwa pengabdian kepada masyarakat merupakan kegiatan sivitas akademika dalam mengalamalkan maupun membudayakan ilmu pengetahuan dan teknologi dalam memajukan kesejahteraan umum dan mencerdaskan kehidupan bangsa (Ocky, 2018).

Sejalan dengan kegiatan pengabdian masyarakat yang merupakan salah satu Tri Dharma Perguruan Tinggi, Universitas Andalas khususnya Campus 2 Universitas Andalas Payakumbuh menggunakan dana BOPTN dibawah naungan Lembaga Penelitian dan Pengabdian Kepada Masyarakat (LPPM) Universitas Andalas pengabdian dalam bentuk wokshop dan sosialisasi Ecommerce Kepada Pedagang Kaki Lima Dan UMKM disekitar Campus 2 Universitas Andalas Kota Payakumbuh.

Kampus 2 Universitas Andalas berada di Kota Payakumbuh. Kota Payakumbuh adalah sebuah kota di provinsi Sumatera Barat, yang memiliki dengan pertumbuhan ekonomi tertinggi di Sumatera Barat. Pertumbuhan ekonomi di Payakumbuh sebesar $6,38 \%$, dan meningkat menjadi $6,79 \%$ pada tahun 2011, pertumbuhan ini berasal dari inovasi dalam bidang sanitasi, pengelolaan sampah, pasar tradisional sehat, pembinaan pedagang kaki lima, dan drainase perkotaan (Wikipedia, 2015).

Menurut data Badan Pusat Statistik 2018, jumlah tenaga kerja berdasarkan skala usaha yang paling banyak menyerap tenaga kerja adalah Usaha Mikro sebesar 57\%.

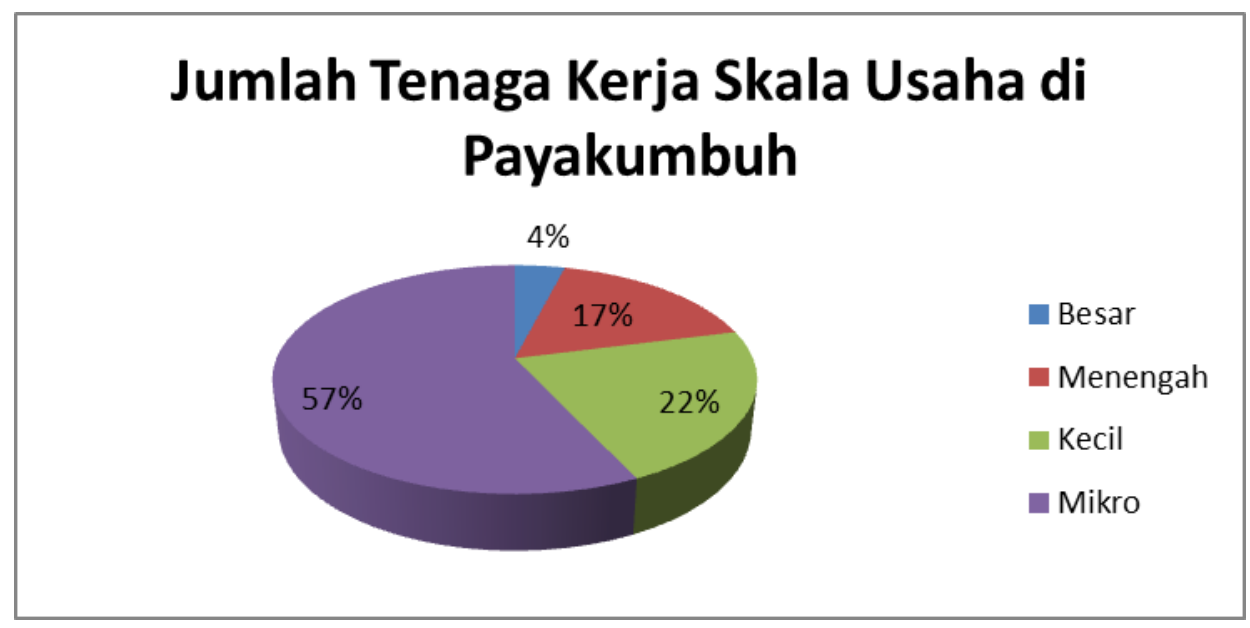

Gambar 1. Jumlah Tenaga Kerja Skala Usaha di Payakumubuh (Sumber: Data BPS 2018)

Payakumbuh memiliki sector unggulan dalam penyerapan tenaga kerja yaitu makanan dan minuman. Secara rata-rata kategori akomodasi makan dan inum ini menyerap 1,58 orang. Kebanyakan usaha ini merupakan kedai minuman, makanan keliling, jualan jus atau jualan pop ice dan kuliner malam. Berdasarkan data Payakumbuh Dalam Angka tahun 2016 untuk pedagang malam tercatat sebanyak 254 pedagang yang sebagian besar menggunakan gerobak. Ciri khas dari Payakumbuh 
terletak pada kulier malamnya karena satu-satunya di Sumatera Barat pedagang kuliner yang buka sampai tengah malam bahkan sampai menjelang subuh itu ada si Payakumbuh. Sehingga pedagang kaki lima mudah sekali ditemui jika berada atau sekedar lewat di Payakumbuh terutama menjelang sore hingga malam hari.

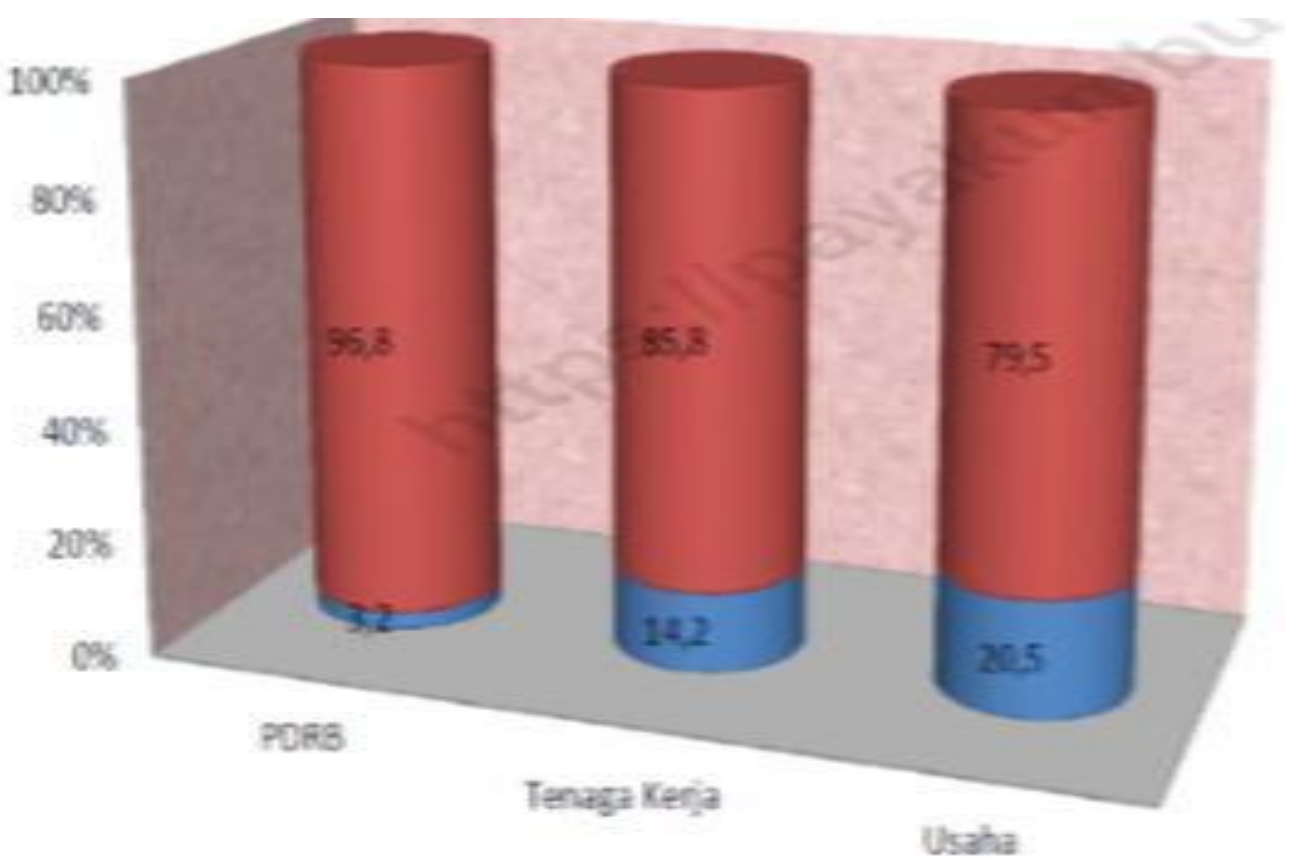

Gambar 2. Kontribusi PDRB, Tenaga Kerja, dan Jumlah Usaha Sektor Akomodasi, Makan dan Minum Kota Payakumbuh, 2016 (Sumber: Data BPS 2018)

Pedagang kaki lima atau yang memiliki gerobak pindah-pindah berjualan pedagang makanan dan minuman sebagian berada di Jl. Lubuh Basilang, sampai sepanjang jalan Soekarno Hatta, Payakumbuh. Kebanyakan pedagang kaki lima ini berada di dekat Campus 2 Universitas Andalas Payakumbuh di Jl. Rangkayo Rasuna Said dan Campus di Jalan Benteng.

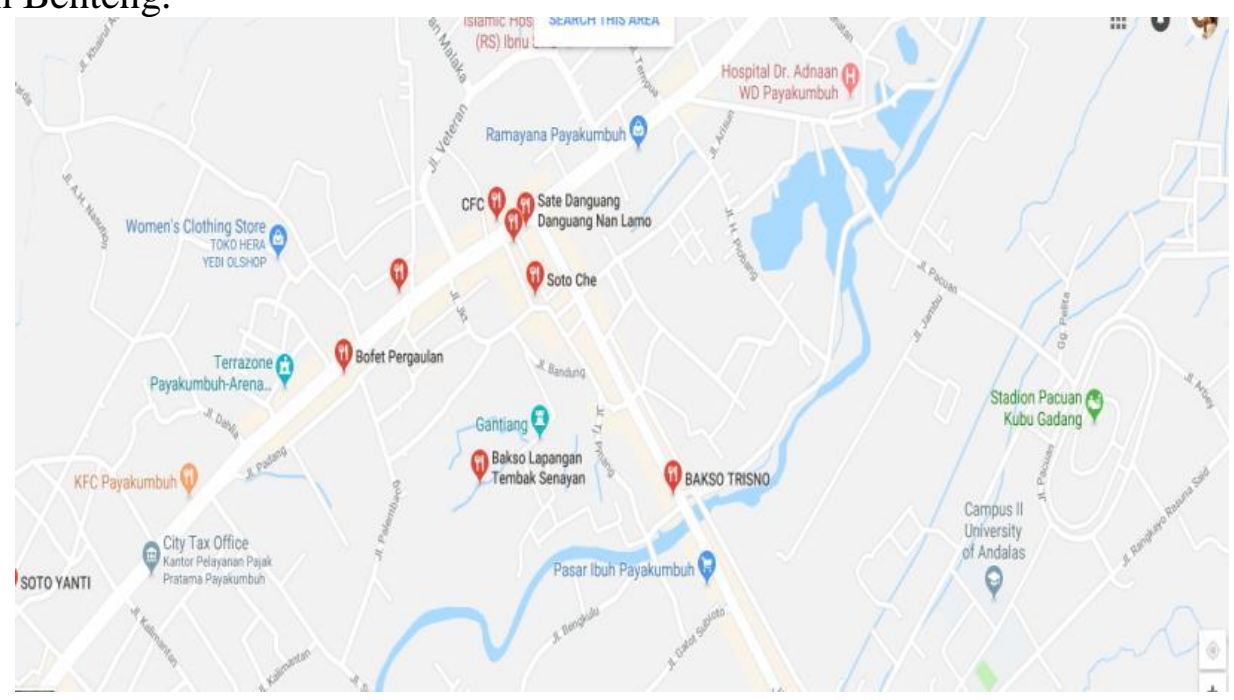

Gambar 3. Peta Sebaran Pedagang Kaki Lima di dekat Campus 2 UNAND Payakumbuh (Sumber: Gogle Maps, 2018 diakses di www.google.maps.com) 
Salah satu pedagang dari 254 pedagang yang sebagian besar menggunakan gerobak yang dapat di pindah-pindah berjualan merupakan pedagang kaki lima yang berjualan minuman khas Payakumbuh yaitu air Banto. Air Bantu yang dijual seharga Rp4.000 per gelas dan tersebar mulai dari Jalan Lubuh Basilang hingga ke Jalan Soekarno Hatta, Payakumbuh. Seperti namanya, Air Banto ini berasal dari perasan air rumput banto yang sangat baik pada kesehatan karena Air Banto dinilai berkhasiat bisa menghilangkan racun-racun dalam tubuh, serta penyakit asma, dan sesak nafas. Namun karena kurang promosi sehingga Air Banto hanya dikenal di kawasan Payakumbuh dan Sumetara Barat saja.

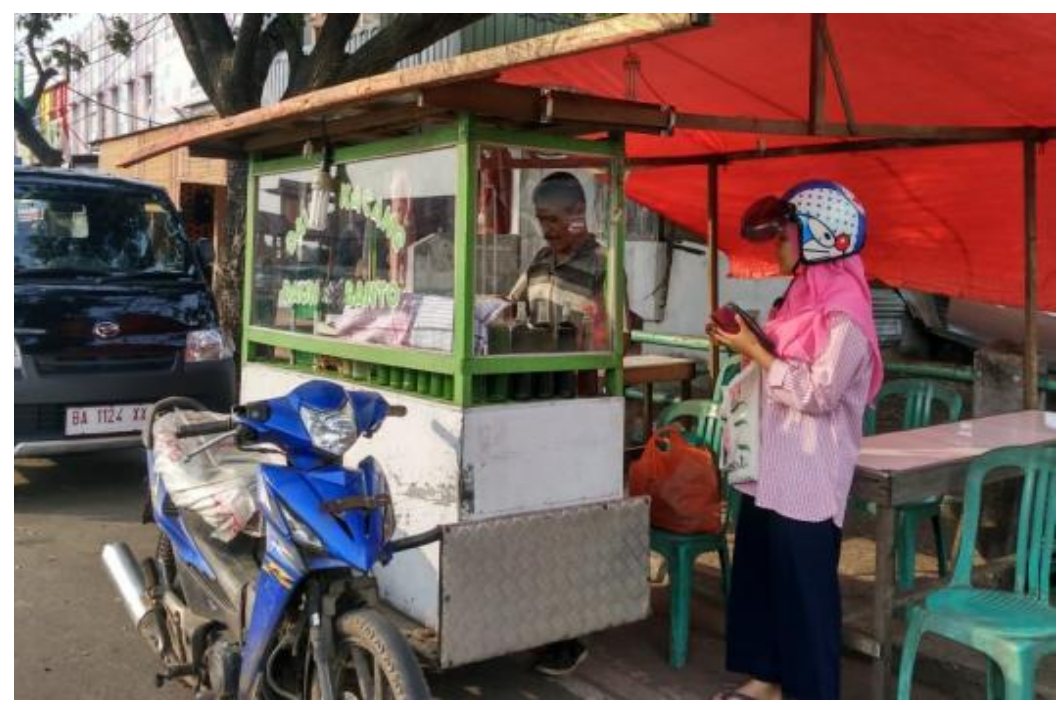

Gambar 4. Pedagang Kaki Lima Air Banto di Pasar Ibuh, Payakumbuh

Tidak hanya pedagang Banto saja, masih banyak pedagang kaki lima yang kurang memiliki sarana promosi untuk meningkatkan penjualannya karena minimnya perhatian kepada pedagang kaki lima. Salah satu cara mempromosikan hasil dagang pedagang minuman Banto dan pedagang lainnnya yang berada di Payakumbuh dengan memanfaatkan teknologi.

Menurut Zein M Muktaf (2016), konsep jual beli dalam masyarakat terus mengalami perubahan dari bentuk penjualan sederhana menuju era digital. Penjualan yang dulunya harus membuka lapak di ruang publik lalu melakukan personal selling dimana penjual dan calon pembeli saling berhadapan serta melihat respon masingmasing kini sudah berubah terutama di era medi seperti internet dan smartphone. Pembeli dan penjual tidak harus tatap muka untuk melakukan kegiatan jual beli.

Rumningsih (2010), perkembangan teknologi yang pesat mempengaruhi cara berpikir seseorang untuk berpikir secara cepat, tepat, dan praktis. Hal ini menjadikan motivasi bagi suatu instansi untuk lebih meningkatkan usaha pelayanannya.

Menurut Berthon, College, Pitt, and Fraser S. (2008), mengapa menggunakan internet karena dengan adanya tantangan dari lingkungan maka sebuah usaha memiliki 3 tantangan utama yaitu ketidakefisienan resiko, resiko permintaan dan resiko inovasi. Dan ketiga resiko ini dapat dikurnagi dengan pemakain internet.

E-commerce merupakan proses pembelian, penjualan, baik produk maupun jasa serta adanya pertukaran informasi melalui jaringan informasi melalui Internet (Kozinets 
et al., 2010). E-commerce mengizinkan produsen untuk menjual produk-produk dan jasa secara online. Calon pelanggan atau konsumen dapat menemukan website produsen, membaca dan melihat produk-produk, memesan dan membayar produkproduk secara online.

Menurut Nanehkaran (2013) e-commerce memiliki beberapa klasifikasi dan memiliki perbedaan metode. Salah satunya ialah jenis B2B atau Business to Business. B2B atau Business to Business merupakan tipe transaksi yang menghubungkan sebuah traksaksi bisnis dengan perusahaan. Misalnya dalam penjualan online melalui webiste. Website adalah cara yang mudah untuk memasarkan bisnis berupa produk atau jasa. Penggunaan teknologi pada era globalisasi ini harus bisa dilakukan.

Sejalan dengan kegiatan pengabdian yang dilakukan oleh Lathifah Arief et.al (2017) dalam Hilirisasi LPPM Unand, hasil ekgiatan dengan adanya teknologi Bluetooth dan RFID pada system otomasi web Nagasi BUMNag sehingga hasilnya didapatka keberadaan staff kanagarian di lingkurngan kerjanya. Dengan adanya kegiatan pengabdian maka web dari Nagari BUMNag menjadi lebih professional dengan pembelian hosting badi Pemerinatahan Nagari Durian Gadang.

Pengabdian untuk pelatihan web juga pernah dilakukan oleh Fajril Akbar dkk (2016) di SMA N 1 Tilatang Kamang di Kabupaten Agam dimana kegiatan ini melakukan pelatihan keapda siswa-siswi tentang pembuatan web dan memberikan gambaran mengenai perancangan basis data dan system informasi geografis. Untuk itu sejalan dengan pembuatan web bagi pedangang kaki lima dan UMKM di Kota Payakumbuh.

Dari data BPS (2018) jumlah tenaga kerja di Kota Payakumbuh mayoritas berpendidikan SMA. Sebesar 21\% merupakan tamatan SMP. Sehingga Sebagai Universitas yang dekat dengan pedagang kaki lima, maka diperlukan pemberian pelatihan mengenai teknologi kepada pedagang kaki lima khususnya mengenai $e$ commerce dengan cara pembuatan website untuk meningkatkan pendapatan pedagang kaki lima.

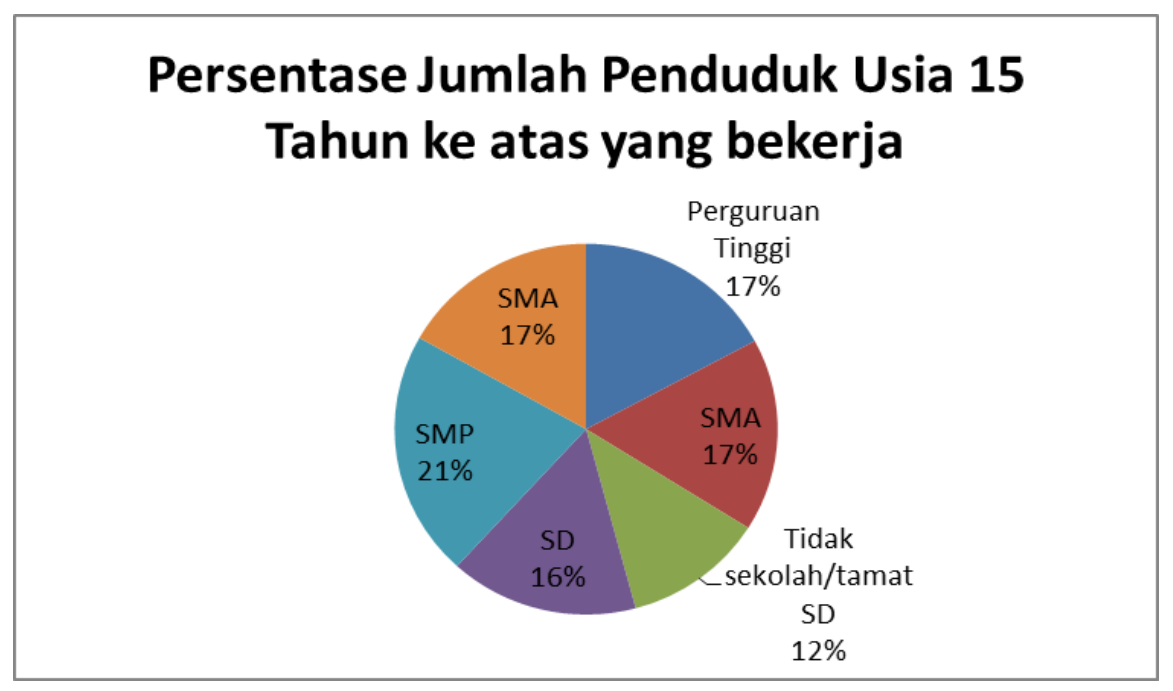

Gambar 5. Persentase Jumlah Penduduk Usia 15 Tahun Ke Atas Yang Bekerja di Payakumbuh 
Permasalahan yang dihadapi oleh para pedagang kaki lima dan UMKM di Kota Payakumbuh yang ingin dibantu pemecahannya adalah:

1. Minimnya pengetahuan peserta tentang penggunaan intenet

2. Kurangnya pengetahuan dan kreatifitas peserta dalam pemanfaatan social media sebagai sarana promosi penjualan

3. Keterbatasan dana untuk membeli gadget atau alat pendukung teknologi seperti Handphone maupun computer.

Dari permsalahan yang dihadapi oleh pedagang kaki lima dan UMKM Kota Payakumbuh maka tujuan diadakan kegiatan pengabdian:

1. Untuk meningkatkan pendapatan pedagang kaki lima disekitar Campus 2 UNAND, Payakumbuh melalui pemanfaatan teknologi.

2. Menambah wawasan dan pengetahuan kepada pedagang kaki Lima di Payakumbuh tentang teknologi khususnya dalam e-commerce.

3. Memberikan pengalaman kepada masyarakat untuk memanfaatkan social media sehingga dapat mengikuti perkembangan zaman

4. Memberikan wawasan mengenai pemasaran secara digital sehingga diharapkan para pedagang kaki lima dapat berjualan kapanpun dan dimana saja

5. Memberikan wawasan kepada masyarakat tentang cara membuat email, cara membuat twitter, Instagram dan Fans Facebook serta website untuk menjual hasil dagangan sehingga para pedagang kaki lima Payakumbuh dapat meningkatkan jumlah penjualannya melalui online.

Dengan kegiatan pengabdian Sosialisasi Dan Pelatihan: Ecommerce Kepada Pedagang Kaki Lima Dan Umkm Kota Payakumbuh Untuk Meningkatkan Daya Saing Di Era Global Manfaat yang diadakannya pengabdian adalah:

1. Meningkatnya pendapatan pedagang kaki Lima, Kota Payakumbuh melalui penjualan melalui internet baik melalui website dan social media.

2. Meningkatnya kesejahteraan masyarakat Payakumbuh khususnya masyarakat disekitar kampus.

Supaya pengabdian ini terarah dengan baik, maka pelaksanan kegiatan pengabdian berupa pelatihan dan workshop melakukan analistis:

1. Pengabdian merupakan pelatihan meningkatkan pendapatan dengan membuat website untuk para pedagang kaki lima Kota Payakumbuh.

2. Peserta berasal dari masyarakat sekitar kampus 2 UNAND, Kota Payakumbuh

3. Pengabdian dan pelatihan diadakan selama satu hari dengan metode pelatihan dan praktek langsung.

\section{METODE}

Kegiatan ini akan dijalankan dalam beberapa tahapan sebagai berikut:

a. Tahap Persiapan Kegiatan

Pada tahap ini kegiatan yang akan dilaksanakan adalah:

1. Sosialisasi dengan Pemerintah dan Institusi terkait, dalam hal ini Izin pemakaian ruangan Aula Campus 2 Universitas Andalas Payakumbuh 
2. Menghubungi masyarakat khususnya pedagang kaki lima sekitar Campus 2 UNAND untuk menentukan jadwal kegiatan. Target peserta sebanyak 10-30 orang.

3. Menyusun bahan untuk pelatihan

4. Mempersiapkan pelaksanaan pelatihan dan pembelian bahan untuk kegiatan pelatihan.

b. Tahap Pelaksanaan Kegiatan

Kegiatan ini dilaksanakan dengan metode pelatihan, praktek oleh seorang instruktur selama satu hari dan diskusi untuk meningkatkan pengetahuan tentang e-commerce dengan para pelaksana program.

Kegiatan pengabdian Seminar dan Workshop Pelatihan Ecommerce Kepada Pedagang Kaki Lima Dan UMKM Kota Payakumbuh Untuk Meningkatkan Daya Saing Di Era Global telah dilakukan pada hari Senin tanggal 19 November 2018 bertempat di Aula Lantai 3 Universitas Andalas Campus 2 Payakumbuh Jl. Rangkayo Rasuna Said, Kubu Gadang, Payakumbuh, Sumatera Barat. Tema dari kegiatan ini untuk meningkatkan Daya Saing di Era Global. Panitia dari acara berupa Dosen Campus 2 Universitas Andalas, Payakumbuh Jurusan Managemen dan Ilmu Ekonomi dengan peserta yang terdiri dari Pedagang Kaki Lima dan UMKM sekitar Campus 2 Universitas Andalas Payakumbuh.

c. Tahap Evaluasi dan Laporan Kegiatan

Mengevaluasi seluruh hasil kegiatan dan membuat laporan akhir kegiatan. Dalam sesi akhir kemudian peserta diberiakan kuesioner mengenai pendapat mengikuti program Seminar dan Workshop Pelatihan Ecommerce Kepada Pedagang Kaki Lima Dan UMKM Kota Payakumbuh.

Metode kegiatan yang digunakan terdiri dari :

1. Metode Pelatihan (Dalam bentuk ceramah)

Pelatihan dilakukan dengan memberikan materi kepada peserta kegiatan yang terdiri dari (1) pengenalan tentang pemasaran (2) memberikan pengetahuan tentang cara menggunakan media social yaitu pembuatan email dan Instagram serta facebook (3) penjelasan pembuatan website.

2. Metode Praktik langsung

Setelah pemaparan materi, peserta langsung mempraktekkan teori yang dipelajari dengan membuat akun email, facebook, instagram dari peserta. Kemudian peserta juga memiliki website bersama untuk digunakan.

3. Follow up kegiatan

Setelah kegiatan selesai, peserta memberikan pendapatnya mengenai kegiatan untuk memberikan gambaran kepada panitia kegiatan demi perbaikan (continues improvement). 


\section{HASIL DAN PEMBAHASAN}

\section{Pelaksanaan Kegiatan}

Acara sosialisasi dan pelatihan yang bertema "Meningkatkan Daya Saing di Era Global" diselenggarakan oleh Program Studi Manajemen Universitas Andalas Kampus II Payakumbuh. Kegiatan wokshop dan sosialisasi Ecommerce kepada Pedagang Kaki Lima Dan UMKM disekitar Campus 2 UNAND Kota Payakumbuh dimulai dari pukul 09.00 WIB pada hari Senin tanggal 19 November yang dihadiri oleh masyarakat sekitar Universitas Andalas Campus 2 Payakumbuh J1. Rangkayo Rasuna Said, Kubu Gadang, Payakumbuh, Sumatera Barat.

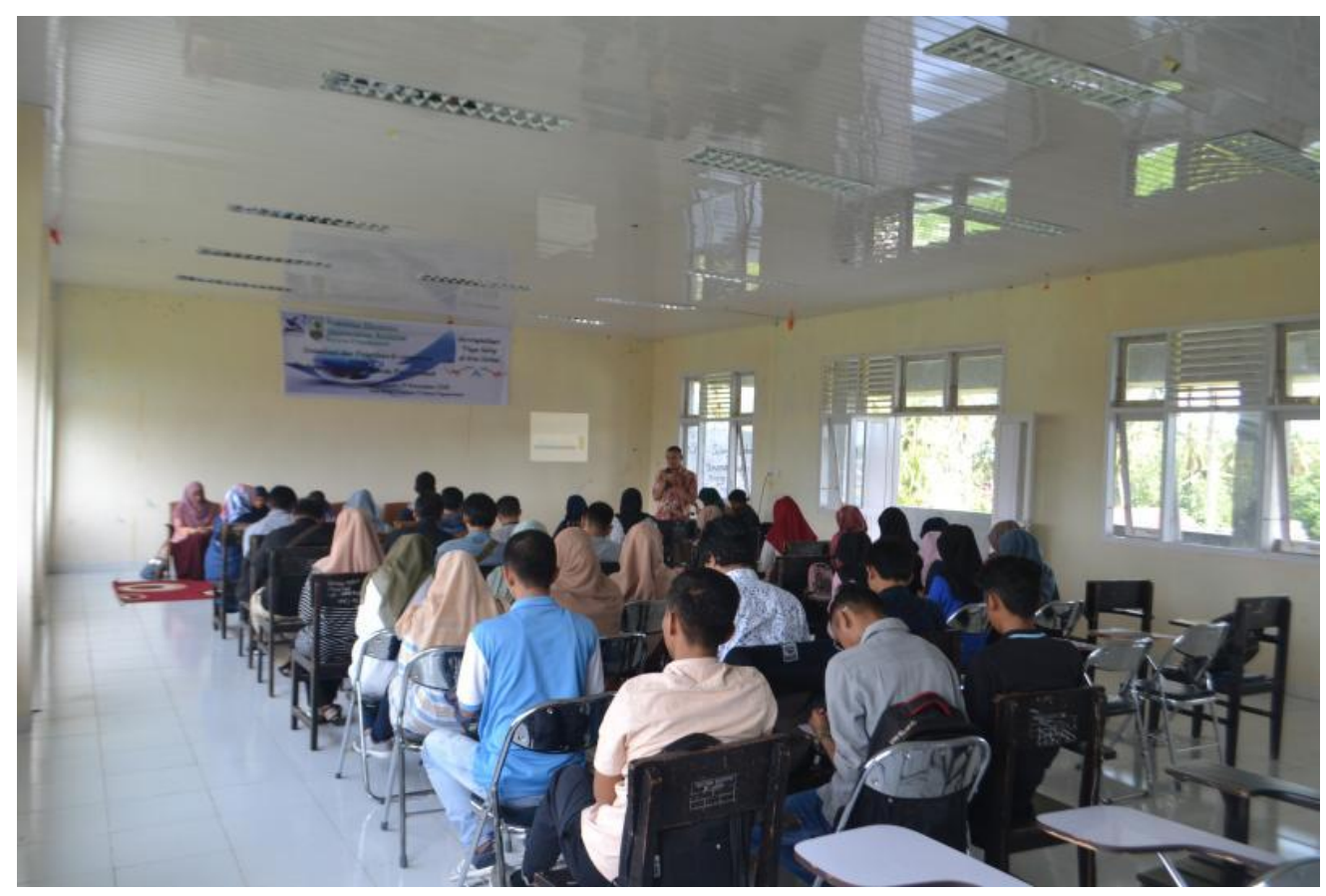

Gambar 6. Peserta Berkumpul Untuk Mengikuti Kegiatan Sosialisasi dan Pengabdian

Setelah peserta berkumpul di tempat kegiatan maka acara pun dimulai. Dalam kegiatan acara diawali dengan pembukaan oleh moderator dalam hal ini Suci. Kemudian dilanjutkan dengan pelantunan ayat suci Al-Quran oleh Bapak Faisal Ali Ahmad Sp. M.Si lalu kata sambutan yang disampaikan oleh Pak Agestayani selaku Sekretaris Program Studi Manajemen Universitas Andalas Kampus II Payakumbuh dan sekaligus Ketua Panitia Sosialisasi dan Pelatihan. Beliau sekaligus membuka acara sosialisasi dan pelatihan yang disambut antusias dari peserta. 


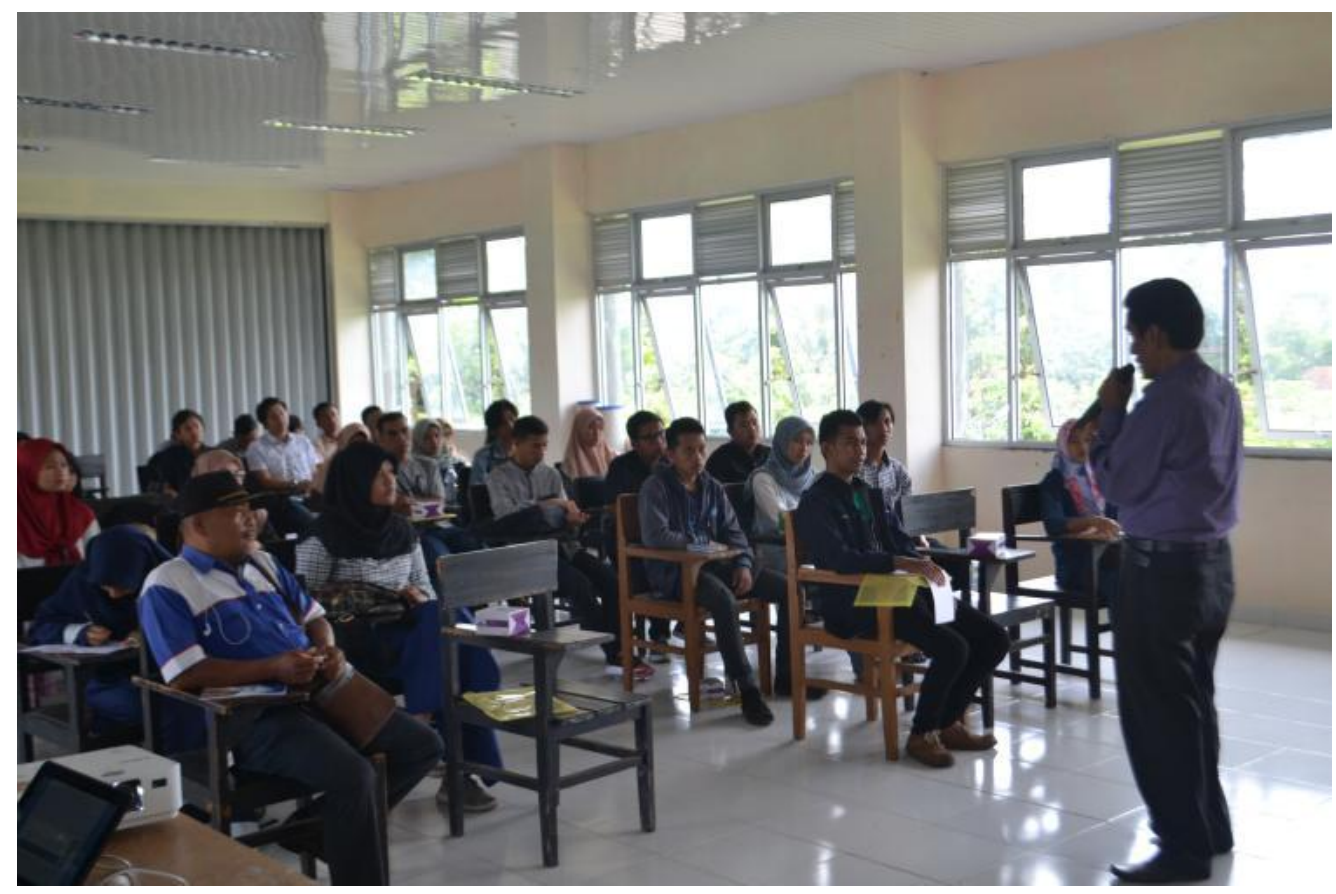

Gambar 7. Pembukaan Sosialisi dan Workshop E-commerce

Kegiatan sosialisasi dan pelatihan Ecommerce kepada pedagang kaki lima dan UMKM Kota Payakumbuh untuk meningkatkan daya saing di era global, beliau menjelaskan bahwa di zaman serba online, penjual harus bisa menguasai teknologi. Adanya pembuatan website maka pedagang kaki lima dan UMKM lebih mempromosikan hasil dagangannya untuk meningkatkan pendapatan. Harapannya agar setelah mengikuti acara peserta termotivasi ilmu yang mereka dapatkan nantinya tidak hilang selepas selesainya acara ini.

Acara selanjutnya penyampaian materi ecommerce dalam hal ini disampaikan oleh Winny Alna Marlina, ST, MM. Penyampaian materi dilakukan dengan dua metode, yaitu metode melalui media pembelajaran dan pembinaan praktek langsung.

Materi berisi tentang cara pembuatan email kepada para pedagang kemudian membuat akun social media kepada pedagang kaki lima, dalam hal ini yang dipakai akun Instagram kemudian dengan membuat website bersama sebagai sarana promosi penjualan dengan pemanfaatan teknologi.

Isi dari materi pelatihan E-commerce terdiri dari:

1. Pembuatan akun email dari Google.com dengan hasil email berupa kulinerpayakumbuh@gmail.com

2. Pembuatan akun instagram dari instagram.com dengan ID @ kulinerpayakumbuh01

3. Pembuatan akun facebook dari facebook.com dengan hasil ID kuliner Payakumbuh

4. Pembuatan website dari wordpress.com

Pedagang yang hadir pun bervariasi mulai dari pedagang makanan tradisional hingga kepada makanan modern seperti putu bambu hingga kebab. Peserta kemudian memberikan photo hasil jualannya berserta alamat, nomor telepon, harga dan spesifikasi 
barang yang akan dijual di dalam website

Untuk website sebagai sarana promosi jualan pedagang kaki lima dan UMKM sekitar Kampus 2 Payakumbuh beralamat di kulinerpayakumbuh.com.
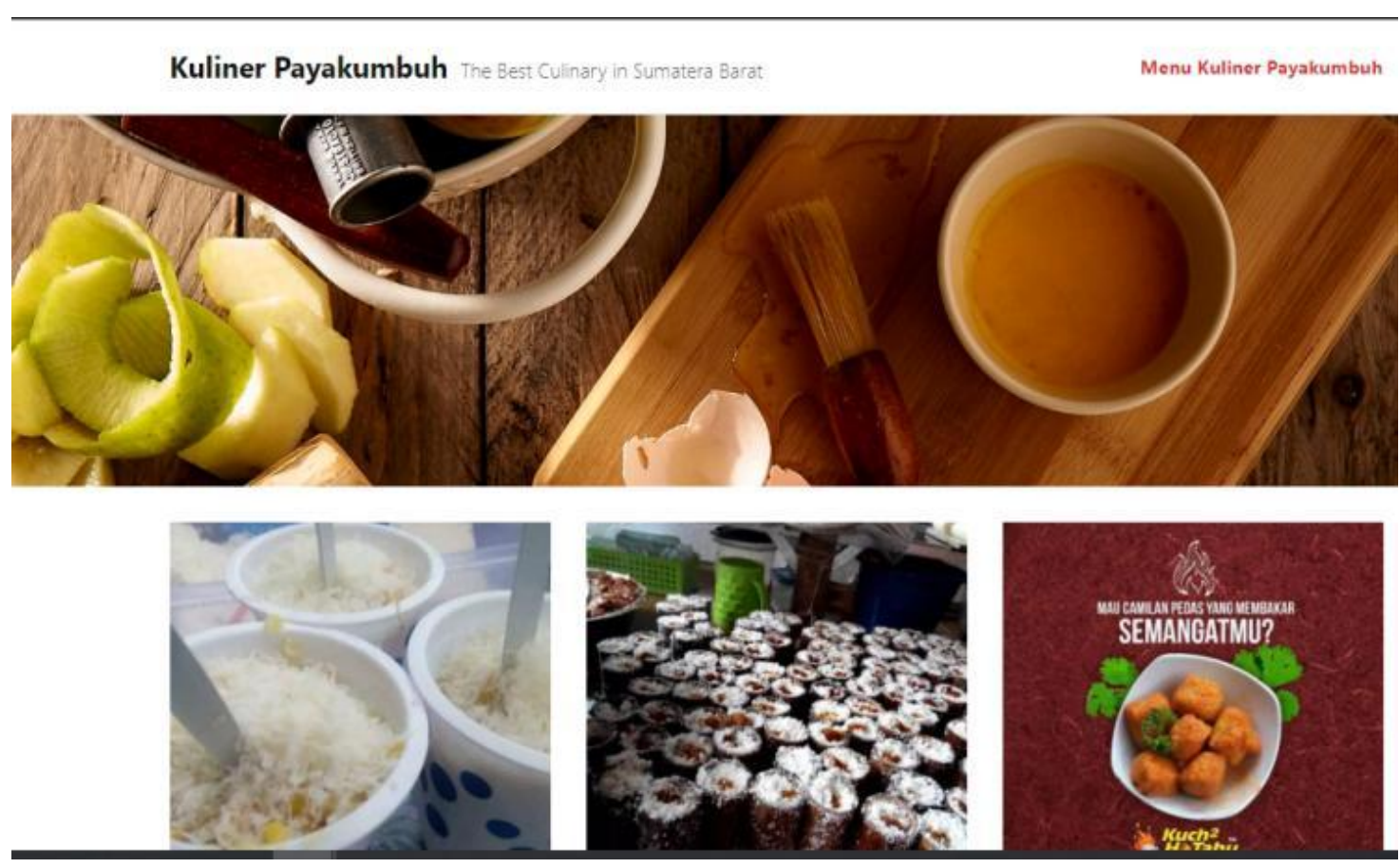

Gambar 8. Website Kuliner Payakumnbuh

Setelah selesai pemaparan dari Narasumber, kemudian dibuka sesi tanya jawab kepada peserta. Seorang perserta bernama Saiful mengemukakan bahwa pedagang kaki lima sudah berubah namanya menjadi pedagang kreatif dan beliau sangat mengapresiasi perhatian dari Universitas Andalas khususnya Campus 2 UNAND Payakumbuh karena merangkul para pedagang UMKM dan Pedagang kaki Lima Kota Payakumbuh. Beliau berharap dengan adanya website ini maka dapat meningkatkan omzet dari penjualannya serta memudahkan pedagang untuk lebih mempromosikan hasil dagangannya dengan menggunakan teknologi yang ada. Artinya jika para pedagang memiliki kendala dan tidak bisa berjualan secara gerobak keliling, berkata adanya website maka penjual tetap bisa berjualan dari rumah. Selain itu diharapkan website kuliner Payakumbuh dapat sebagai ajang terbentuknya komunitas para pedagang kreatif se-Payakumbuh. 


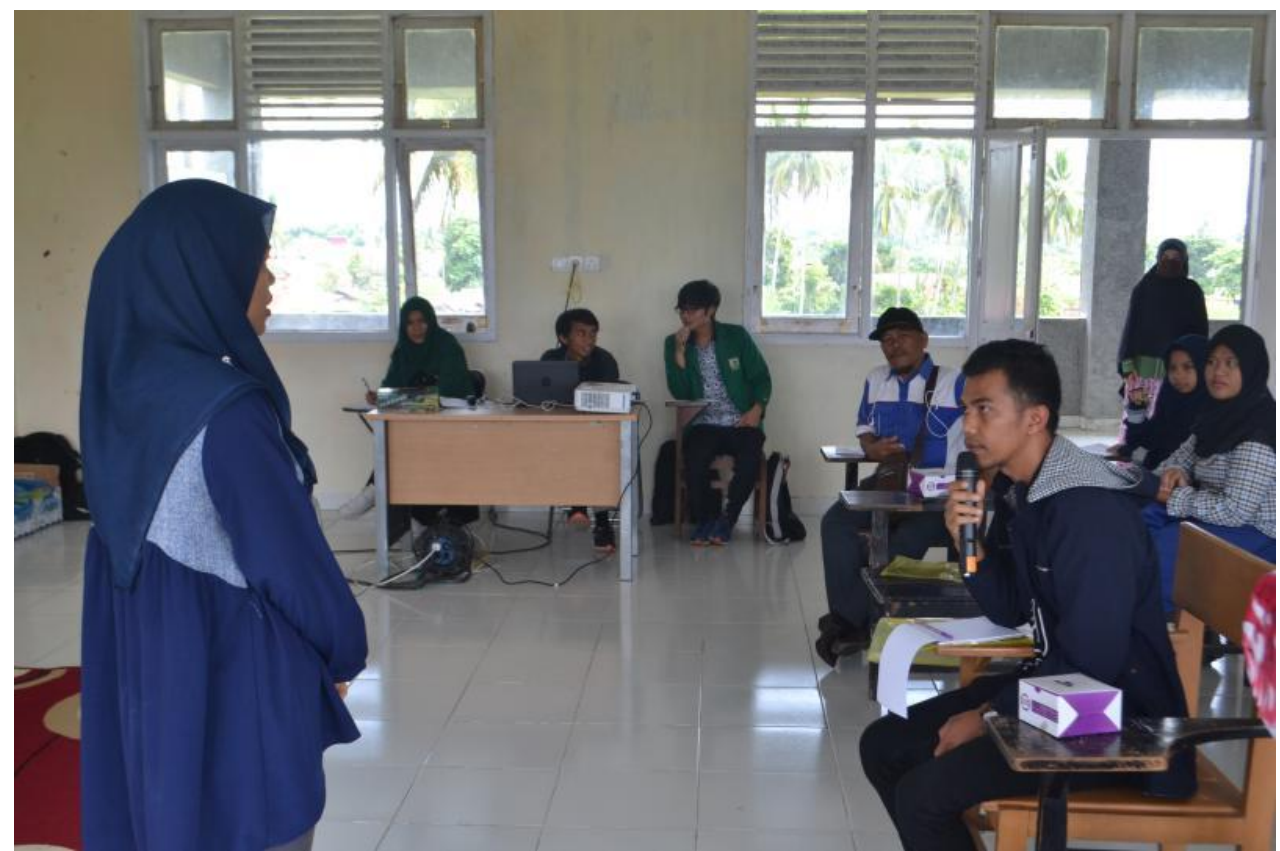

Gambar 9. Tanya Jawab dengan Peserta dan Narasumber

Acara sosialisai dan pelatihan selesai pada pukul 15.30 ditutup dengan photo bersama dengan peserta dan panitia. Peserta yang terdiri dari pedagang kaki lima dan UMKM sekitar Campus 2 Payakumbuh sangat senang dengan diadakannya kegiatan. Para pedagang dan UMKM sekitar kampus 2 UNAND Payakumbuh berterimakasih kepada pihak Universitas Andalas dan berharap kegiatan pengabdian terus dilaksanakan dan tidak hanya sekali saja.

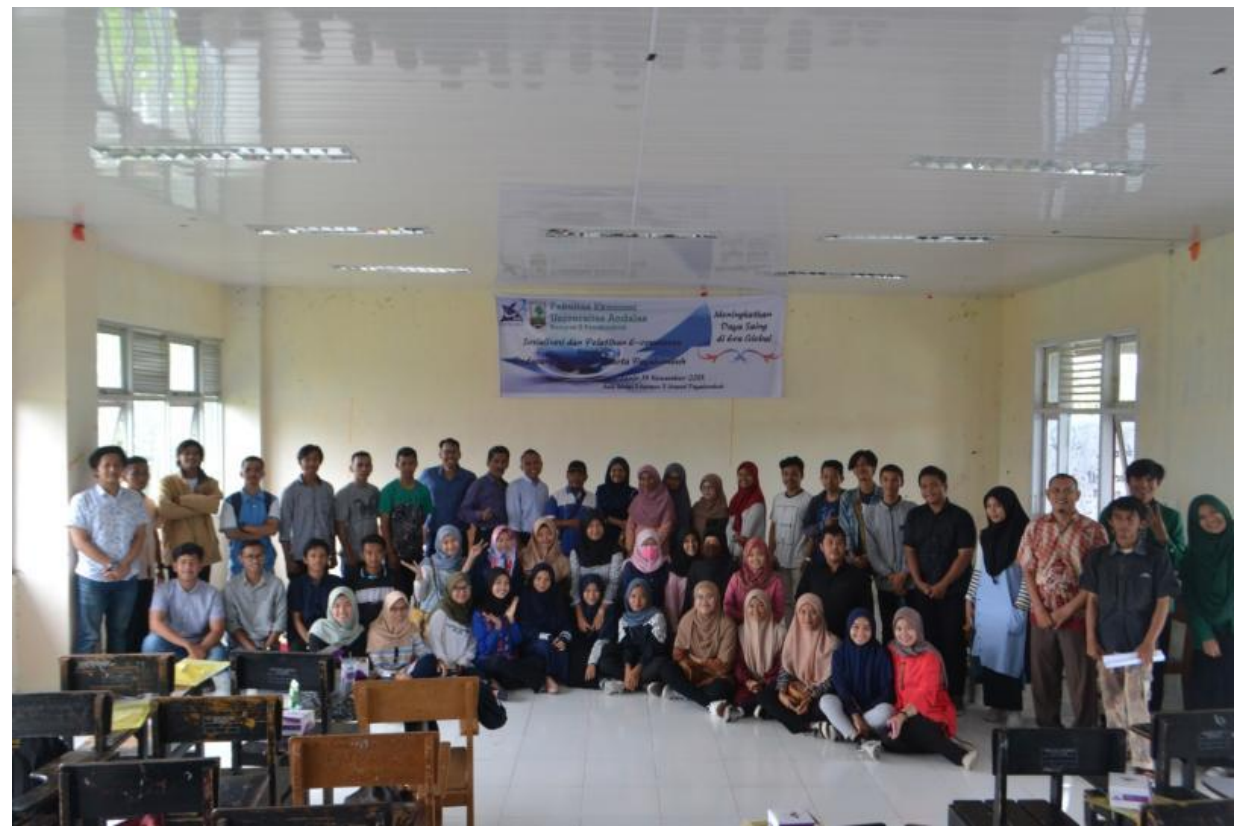

Gambar 10. Acara Seminar dan Workshop Pelatihan Ecommerce Kepada Pedagang Kaki Lima dan UMKM Kota Payakumbuh 
Dari hasil survei setelah acara berlangsung maka di dapat bahwa kedala terbesar yang dihadapi oleh pedagang ialah jualan yang kurang promosi sebesar $42 \%$.

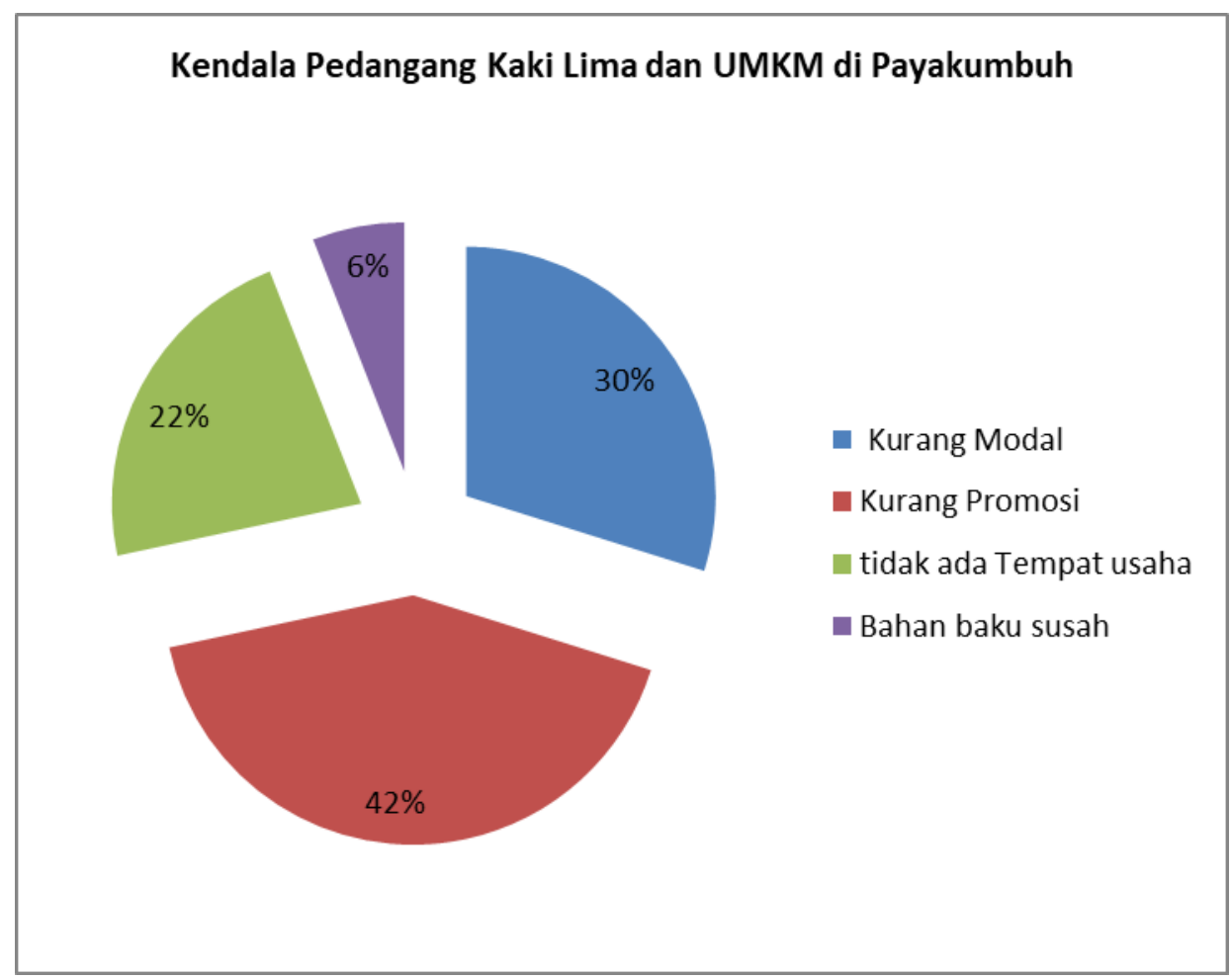

Gambar 11. Kendala yang Dihadapi Pedagang Kaki Lima dan UMKM di Payakumbuh

Setelah diadakan kegiatan $46 \%$ peserta mendapatkan manfaat kegiatan menjadi mengetahui cara promosi dari website, kemudian $41 \%$ menambah wawasan dan $13 \%$ membantu perkembangan usahanya kedepan.

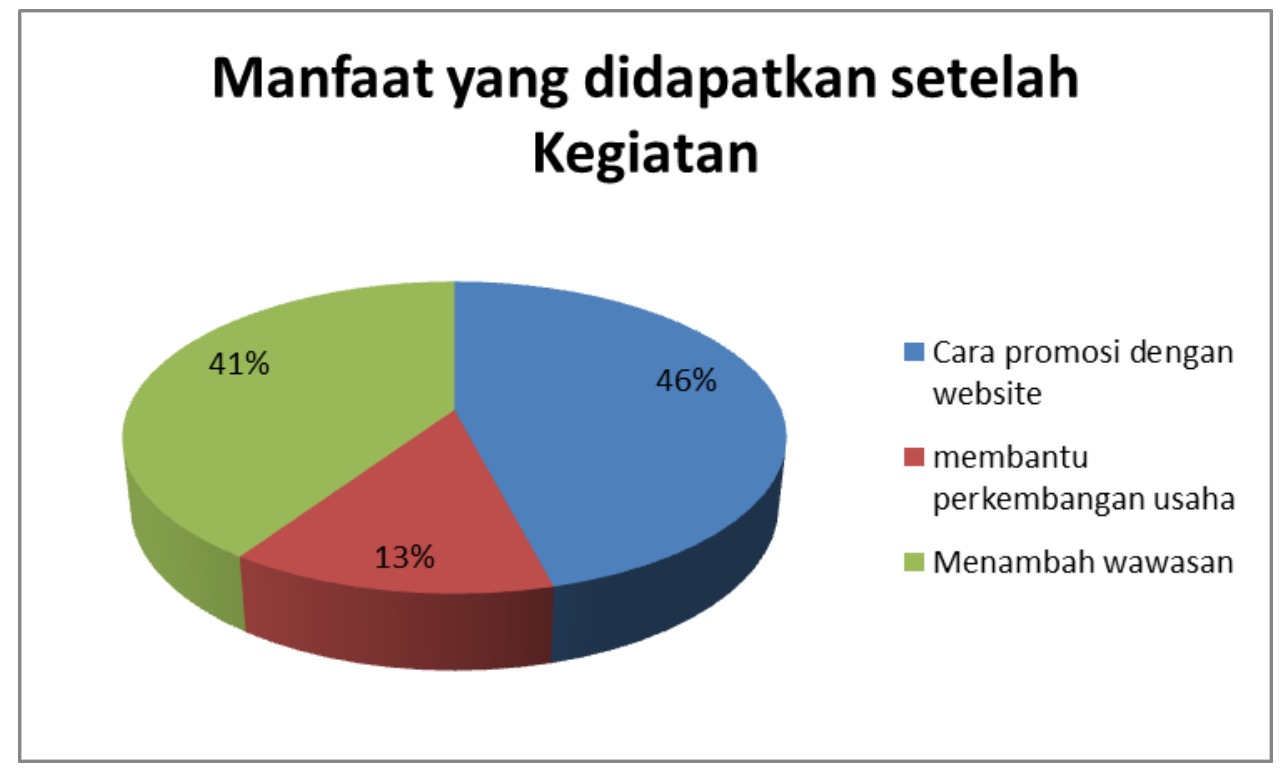

Gambar 12. Manfaat setelah mengikuti Sosialisasi dan Pelatihan 
Untuk harapan setelah mengikuti kegiatan Sosialisasi dan Pelatihan Ecommerce kepada Pedagang Kaki Lima dan UMKM Kota Payakumbuh, peserta berharap dapat menaikkan omzet penjualannya melalui website sebesar $78 \%$ dan $22 \%$ berharap dibuatkan komunitas untuk pedagang kaki lima di Payakumbuh.

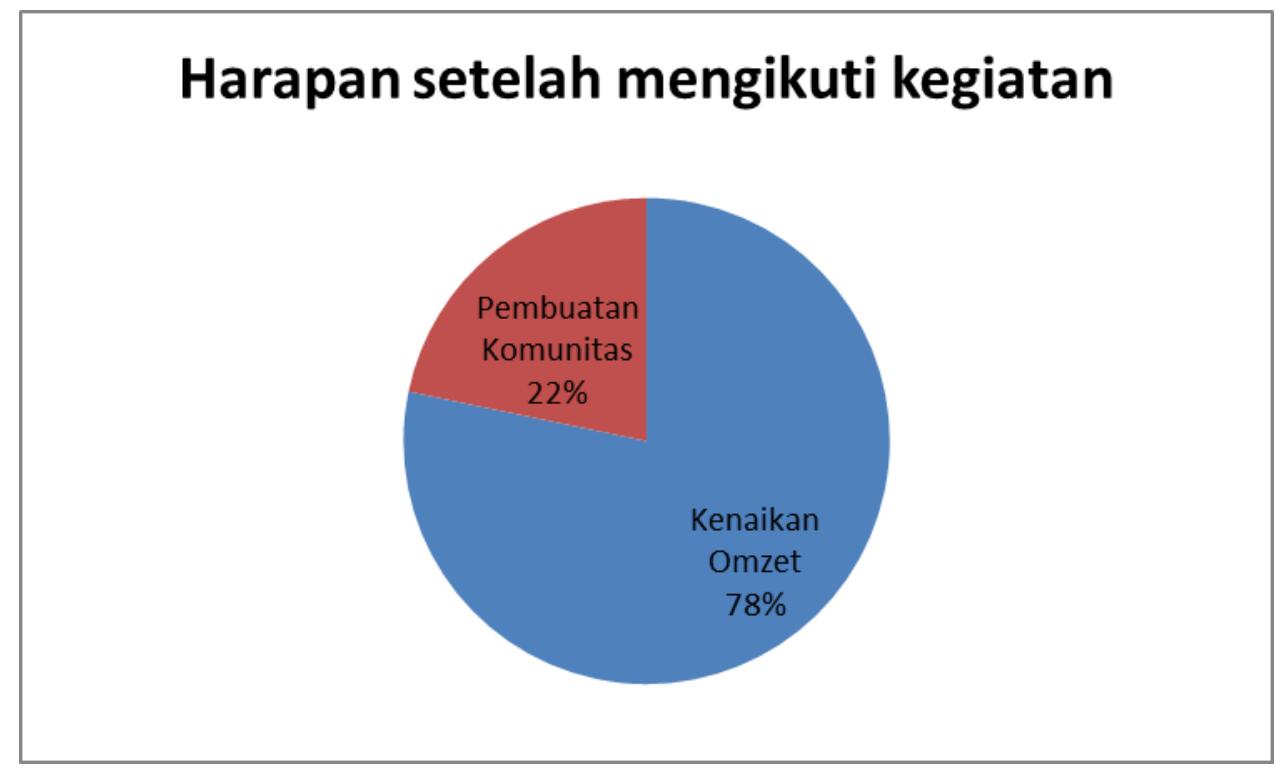

Gambar 13. Harapan Setelah Mengikuti Kegiatan

\section{KESIMPULAN DAN SARAN}

Dari hasil kegiatan Sosialisasi dan Pelatihan Ecommerce kepada Pedagang Kaki Lima dan UMKM Kota Payakumbuh disimpulkan: adanya website kulinerpayakumbuh.com sebagai sarana untuk membantu mempromosikan usaha pedagang kaki lima dan UMKM di Payakumbuh. Peserta kegiatan memahami perlunya e-commerce untuk memasarkan dagangannya dan berharap kegiatan serupa terus dilaksanakan.

\section{UCAPAN TERIMAKASIH}

Terimakasih sebesar-besarnya kepada semua pihak yang telah mendukung terlaksananya kegiatan Sosialisasi dan Pelatihan Ecommerce kepada Pedagang Kaki Lima dan UMKM Kota Payakumbuh terutama pihak Fakultas Ekonomi Universitas Andalas dan Lembaga Penelitian dan Pengabdian Kepada Masyarakat (LPPM) Universitas Andalas serta seluruh peserta dan panitia kegiatan. 


\section{DAFTAR PUSTAKA}

Akbar, F. 2017. Pelatihan Pembangunan Web Bagi Siswa SMAN 1 Tilatang Kamang di Kabupaten Agam. Universitas Andalas, Padang.

Anonim. Payakumbuh. /en.wikipedia.org/wiki/Payakumbuh, diakses tanggal 18 November 2018.

Anonim. Mapsmakananpayakumbuh.http://googlemaps.com diakses tanggal 10 November 2018.

Arief, L. 2017. Pengembangan dan Pelatihan Pengeloloaan Website Berbasis Content Management System (CMS) untuk Pemerintahan Nagari dan Badan Usaha Milik Nagari (BUMNag) Kanagarian Durian Gadang. Universitas Andalas, Padang.

Ardianti R. 2007. Perkembangan Adopsi e-commerce dan Implikasinya bagi Manajemen Organisasi Bisnis.

Berthon P, College B, Pitt LF, and Fraser S. 2008. Electronic Commerce: The Strategic Perspective Electronic Commerce: The Strategic Perspective. Electronic commerce Undergraduate study in Computing and related programmes.

Kozinets, R. V., De Valck, K., Wojnicki, A. C., dan Wilner, S. J. (2010). Networked narratives: Understanding word-of-mouth marketing in online communities. Journal of marketing, 74(2), 71-89

Maryama S. 2013. Penerapan E-Commerce Dalam. 2(1):73-79.

Muktaf, Zein. 2016. E commerce sebagai Agen Konsumsi di Era Media Baru. Yogyakarta. Dipublikasikan di International Conference Social Politic. Universitas Muhammadiyah Yogyakarta, 26-28 Januari 2016

Nanehkaran YA. 2013. An Introduction To Electronic Commerce. 2(4):2-5.

Rumningsih. 2010. Membangun Aplikasi E-Commerce Toko Buku El-Shaddai Membangun. 